\title{
VALIDATION OF TECHNOLOGY COMPONENTS FOR PEANUT POD BORER (Etiella zinckenella Triet.) CONTROL
}

\author{
Yusmani Prayogo \& Marida Santi Yudha Ika Bayu \\ Indonesian Legumes and Tuber Crops Research Institute \\ Jl. Raya Kendalpayak KM 08 Malang 65101 \\ E-mail: yusmani.prayogo@yahoo.com
}

Manuscript received: 14 September 2018. Revision accepted: 3 March 2020

\begin{abstract}
Validation of technology components for peanut pod borer (Etiella zinckenella Triet.) control. Peanut pod borer caused by Etiella zinckenella is one of the important pests of peanut in Indonesia. The symptoms of E. zinckenella attack are blackened pods and rotten seeds, causing yield loss up to $90 \%$. The research aim was to validate the efficacy of various control technology components of peanut pod borer pests. The research was arranged using a randomized complete block design (RCBD), the treatment consisted of six control technology components and treatment was repeated four times. The results showed that the more larvae found in the pods, the greater the damage of the pods are crushed by larvae. Application of lambda cyhalothrin insecticide (P6) starting at 35-70 days after planting (DAP) was not able to suppress larval populations of E. zinckenella so that damaged pods were also larger and not significantly different from control (P0). Lambda cyhalothrin insecticide application also harms the survival of natural enemies (predators and parasitoids). Lambda-cyhalothrin insecticides can be combined with other control components such as soybean trap plants, thiamethoxam and carbofuran and parasitoid Trichogramma bactrae-bactrae) to control of peanut pod borer. Application of Lecanicillium lecanii biopesticide that combined with chemical insecticides thiamethoxam or carbofuran can suppress E. zinckenella larvae and yield loses, beside it can safety against the survival of predators (Araneida and Coleoptera) and parasitoid (Hymenoptera and Diptera). Biopesticides of L. lecanii were combined with thiamethoxam or carbofuran insecticides can be recommended for controlling E. zinckenella the peanut pod borer.
\end{abstract}

Key words: chemical insecticides, E. zinckenella, natural enemy, peanut, pod borer

\section{INTRODUCTION}

Pod borer, Etiella zinckenella Treit. (Lepidoptera: Pyralidae) is an important pest in soybean. These pests are distributed in almost all soybeans production centers in Indonesia (Van den Berg et al., 2000; Tengkano et al., 2006; Tengkano, 2007; Permana et al., 2012; Ganeshi, 2013) and have been reported to attack peanut in Bengkulu with damage rates ranging from 31-48\% (Apriyanto et al., 2008; Apriyanto et al., 2010). Pod borer has also been reported to attack in several peanut production centers in Lampung province and Central Java with endemic criteria (Baliadi, 2006).

The peanut pods which are attacked by pod borer are characterized by boreholes on the pod surface which black and hollow, the damaged seeds then rot and the larvae droppings were found in the pods (Baliadi \& Rahmiana, 2010). Besides, the larvae or pupae of pod borer are often found in damaged pods (Baliadi, 2006; Apriyanto et al., 2009). The losses caused by these pests are quite high with yield losses in peanuts were up to 90\% (Baliadi \& Rahmiana, 2010). In addition, pods that have been brooded by E. zinckenella larvae can trigger the infection of the fungus Aspergillus flavus, which causes peanuts to become highly toxic due to the aflatoxin produced by A. flavus (Hedayati et al., 2007; Reddy et al., 2010).

Pod borer control techniques generally carried out by farmers using chemical insecticides (Abdou \& Abdalla, 2006). However, yield losses due to pod borer attacks in the fields have not been fully overcome yet instead, they are likely to increase. The increase in pod borer attack on peanuts was probably caused by the excessive use of chemical insecticides that kill all pod borer's natural enemies (Rodrigues-Saona et al., 2013). Moreover, the increase in the population of pod borer in the field is also caused by the availability of host plants throughout the season. Several types of plants have been reported as hosts for pod borer, such as soybeans, green beans, snails (Crotalaria juncea), and other types of legume crops (Van den Berg et al., 1998).

Control of these pests is quite difficult because the imago stages develop on plant surfaces, while the larvae develop inside pods that are in the soil. Various 
methods of control have been developed, such as the use of trap crops, the release of Trichogramma bactrae-bactrae parasites, and the use of resistant varieties (Sutrisno et al., 2002; Damayanti et al., 2001), apparently they were not able to significantly suppress the development of pod borer populations in the field. The results of the efficacy test of the combination of several technological components for peanut pod borer control showed positive results at two experimental fields, Kebun Percobaan (KP) Natar (Lampung) and KP Muneng (Probolinggo) (Prayogo et al., 2012). This study aimed to evaluate the efficacy of the technology components for controlling peanut pod borer (E. zinckenella).

\section{MATERIALS AND METHODS}

Research Site. The research was conducted in the KP Natar Experimental field of Assessment Institute for Agricultural Technology (BPTP) Lampung, which is one of the endemic areas of peanut pod borer. The study was conducted from April to August 2014.

Experimental Design. The experiment was arranged using a randomized complete block design (RCBD), with four replications. The treatments used were six control technology components that were assembled based on the results of testing in 2012 (Table 1). The pest control technology components are as follows; P0 (no pest control), P1 (thiamethoxam + carbofuran $+T$. bactraebactrae parasitoid + soybean trap plant + lambdacyhalothrin), P2 (carbofuran $+T$. bactrae-bactrae + soybean traps + lambda-cyhalothrin), P3 (T bactraebactrae + soybean trap plant + lambda-cyhalothrin), $\mathrm{P} 4$ (thiamethoxam + carbofuran + L. lecanii), P5 (thiamethoxam + L. lecanii), and P6 (lambdacyhalothrin).

Land Preparation. The land was processed by twice plowing, then it was softened and added manure as much as 2.5 tons/ha. Each treatment used a $400 \times 500 \mathrm{~cm}$ plot, the distance between plots was $50 \mathrm{~cm}$. Peanuts used in this study were Bison variety, the planting distance was $40 \times 10 \mathrm{~cm}$, with one seed on each planting hole.

The basic fertilizer applied was $50 \mathrm{~kg}$ Urea + $100 \mathrm{~kg} \mathrm{SP} 36+50 \mathrm{~kg} \mathrm{KCl} / \mathrm{ha}$ that ditch along the row of plants at the age of 10 days after planting (DAP). Weeding was done manually at the age of 21 and 45 DAP, while irrigation was done according to the land conditions.

Preparation of Trap Crops. The Wilis variety of soybean was used as a trap for E. zinckenella imago. Trap crops were planted around each treatment plot 14 days before planting the peanuts expecting that, when the peanut was flowering, the soybean had formed pods. Thus, E. zinckenella imago can collect on the legumes of soybeans because soybeans are the main host of pod borer.

Preparation of Experimental Plants. Peanut seeds for P1 (thiamethoxam + carbofuran $+T$. bactraebactrae + soybean trap crop + lambda-cyhalothrin + L. lecanii) and $\mathrm{P} 4$ (thiamethoxam + carbofuran + L. lecanii) treatments were treated with chemical insecticide contain thiamethoxam before planting. The peanut seeds for P1, P2 (carbofuran $+T$. bactraebactrae + soybean trap crop + lambda-cyhalothrin), and $\mathrm{P} 4$ treatments at planting time were sprayed by

Table 1. Peanut pod borer (E. zinckenella) pest control technology components

\begin{tabular}{ccccccc}
\hline Treatment & Thiamethoxam & Carbofuran & $\begin{array}{c}\text { T. bactrae- } \\
\text { bactrae }\end{array}$ & Trap crops & $\begin{array}{c}\text { Labmda- } \\
\text { cyhalothrin }\end{array}$ & L. lecanii \\
\hline P0 & - & - & - & - & - & - \\
P1 & + & + & + & + & + & - \\
P2 & - & + & + & + & + & - \\
P3 & - & - & + & + & - & + \\
P4 & + & - & - & - & - & + \\
P5 & + & - & - & - & + & - \\
P6 & - & Planting & 35 DAP & 14 days & 35-70 DAP & 35-70 DAP \\
Application & Seed & (planting hole) & & before & (weekly) & (weekly) \\
time & treatment & & & planting &
\end{tabular}

$(+)$ application of each component of pest control technology; (-) no pest control. 
insecticides containing carbofuran on the planting holes at a dose of $20 \mathrm{~kg} / \mathrm{ha}$. Thiamethoxam insecticide with a dose of $2 \mathrm{~mL} / \mathrm{L}$ of water mixed with seeds before planting.

\section{Preparation and Infestation of $T$. bactrae-bactrae.} The imago of T. bactrae-bactrae was obtained from the Indonesian Sweetener and Fiber Crops Research Institute (ISFCRI) and then propagated on Corcyra cephalonica eggs which were attached to paper sheets. C. cephalonica eggs that had been parasitized by T. bactrae-bactrae for the next six days were invested in each treatment plot at the age of 35 DAP with a population of $15,000 \mathrm{head} / \mathrm{ha}$. Biopesticide containing active conidia of entomopathogen fungi, L. lecanii with conidia density of $10^{7}$ conidia $/ \mathrm{mL}$ were applied weekly from the age of 35-70 DAP by spraying it into the flower's formation as a candidate for gynophore. Application dose of L. lecanii biopesticide was $2 \mathrm{~mL} /$ plant, spray volume $500 \mathrm{~L} / \mathrm{ha}$ with a population of 250,000 plants/ha. Lambda-cyhalothrin insecticide application was applied every week seven times from the age of 35-70 DAP with the same spray volume as L. lecanii biopesticide.

Observed Variables and Data Analysis. Observed variables were: (1) intensity of pod damage due to E. zinckenella larvae in 10 clumps of plants were taken randomly at harvest, (2) pest types and populations were observed in 10 clumps starting 42, 49, 56, and 63 DAP, in addition, it was also caught by using sweepnets which were swung five times at each treatment plot, the captured insects then observed in the laboratory and identified based on the determination key (Norton et al., 2000), (3) species and populations of natural enemies were visually observed in 10 clumps of plants and captured using insect nets in each plot from the age of $42,49,56$, and 63 DAP then identified in the laboratory using determination key (Norton et al., 2000; Schell \& Latchininsky, 2007), (4) the total number of pods/10 clumps of plants, (5) the number of E. zinckenella pods/ 10 clumps of plants, (6) dry pod weight/plot measuring $10 \mathrm{~m}^{2}$. The attack rate of E. zinckenella on peanut was calculated using the following formula:

$$
\mathrm{DI}=\frac{\sum \mathrm{Pd}}{\sum \mathrm{Pt}} \times 100 \%
$$

$\mathrm{DI}=$ damage intensity

$\mathrm{Pd}=$ damaged pods caused by E. zinckenella

$\mathrm{Pt}=$ total of observed pods

All data obtained were analyzed using the MINITAB program version 14 . Then, if there were differences between treatments, the Duncan's Multiple Range Test was calculated at the significant level $\alpha=0.05$.

\section{RESULTS AND DISCUSSION}

The Number of $\boldsymbol{E}$. zinckenella Larvae. The results showed that the number of larvae found ranged between 3-20/five clumps of plants at each plot. The highest number of E. zinckenella larvae was found in the P6 treatment (lambda-thiamethoxam chemical insecticide

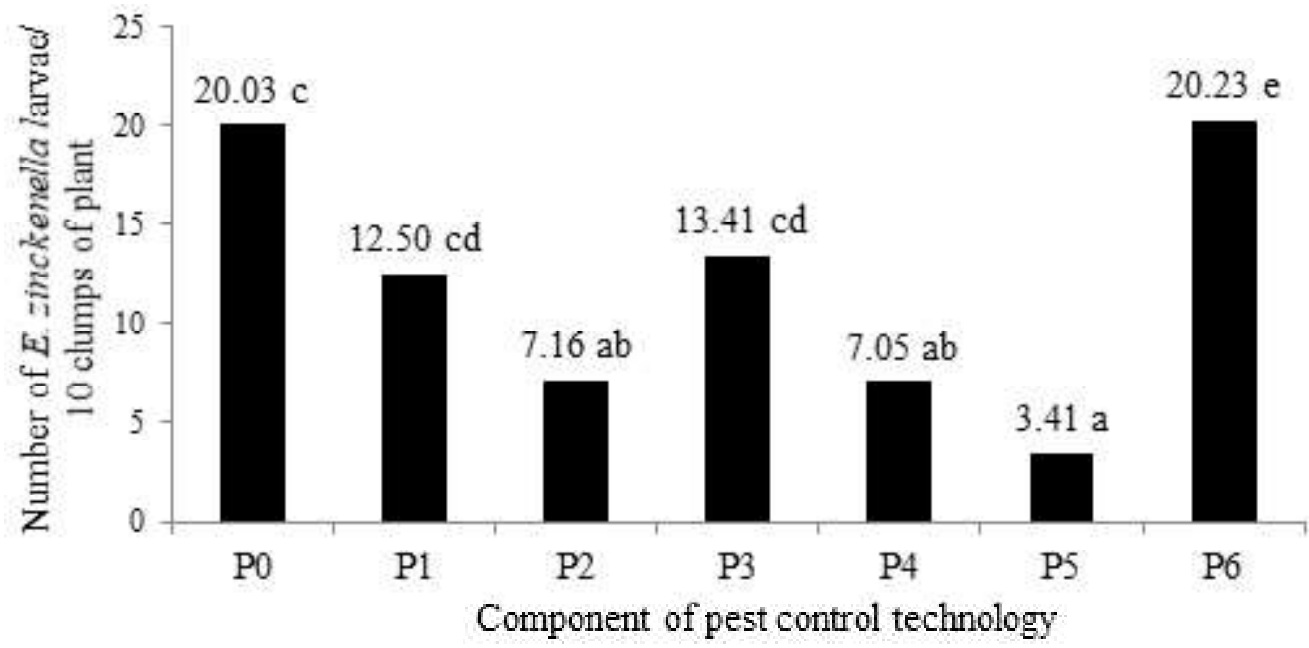

Figure 1. Number of E. zinckenella larvae on the peanut pod/10 clumps of plant at each plot. P0 (no pest control); $\mathrm{P} 1$ (thiamethoxam + carbofuran + T. bactrae-bactrae + trap crops + lambda-cyhalothrin); P2 (carbofuran + T. bactrae-bactrae + trap crops + lambda-cyhalothrin); P3 (T. bactrae-bactrae + trap crops + lambdacyhalothrin); P4 (thiamethoxam + carbofuran + L. lecanii); P5 (thiamethoxam + L. lecanii); and P6 (lambda-cyhalothrin). 
application) and control (P0), however, the two treatments were not significantly different (Figure 1). The high number of larvae found in the P0 treatment was due to the research site as an endemic area for pod borer, thus insects naturally develop in every season. The pod borer larvae population observed at P6 was up to 20 , it was suspected that the chemical insecticide compound, lambda-cyhalothrin, which was applied could only kill the imago on the surface of the plant. Meanwhile, the larval stage in the pod remained alive because the chemical insecticide compound was unable to reach in the soil where the pods are formed. In addition, the chemical insecticide compound which is applied is not ovicidal (kills eggs) so that the eggs continue to develop normally into larvae and imago.

The pod borer larvae population in the $\mathrm{P} 1$ and $\mathrm{P} 3$ treatments was also quite high, ranging from 12-13/10 clumps of plants. At P2 treatment, seven pod borer larvae were observed and not significantly different from $\mathrm{P} 4$. The lowest population of E. zinckenella larvae was three for every 10 clumps of plants observed in the P5 treatment (thiamethoxam + L. lecanii). Based on the number of observed pod borer larvae, the P5 treatment was able to suppress the development rate of pod borer populations compared to other treatments. The low number of larvae population in the P5 treatment caused by the thiamethoxam insecticide applied at the time of planting which able to induce plant systemic resistance. Meanwhile, L. lecanii which was applied during flowering was assumed to be able to infect a group of pod borer eggs placed by the imago on the flower petals. Furthermore, eggs that have been infected with L. lecanii eventually can not hatch to larvae so that the flower that develops into a gynophore and enters the soil is free from E. zinckenella larvae attacks. This condition occurs because the L. lecanii was ovicidal, which able to thwart the hatching of insect eggs or kill the egg. The ovicidal nature of $L$. lecanii against whitefly eggs (Aleurodicus disperses) was reported by Thangavel et al. (2013). Prayogo (2009) also reported that $L$. lecanii was ovicidal against soybean pod sucking eggs (Riptortus linearis) so that the infected eggs did not hatch until they reached $90 \%$. The ovicidal ability of the $L$. lecanii fungus was characterized by producing several types of enzymes and toxins, including; chitinase, protease, lipase, and amylase (Isaka et al., 2005). In addition, this fungus also produces several types of toxins namely dipicolinic acid, hydroxycarboxylic acid, and cyclosporine to kill its host (Murakoshi et al., 2005).

The Pod Borer (E. zinckenella) Larvae. The level of damage to peanuts due to E. zinckenella attacks can be calculated from the percentage of pods picked up by larvae. The more larvae found in pods, the greater the chance of pod damage. The results showed that damaged pods by E. zinckenella were ranged from $13.51-30.33 \%$ (Figure 2). The P6 treatment showed the highest pod damage $(30.33 \%)$, and the treatment was not significantly different from $\mathrm{P} 0$. The results of this study indicated that the application of chemical

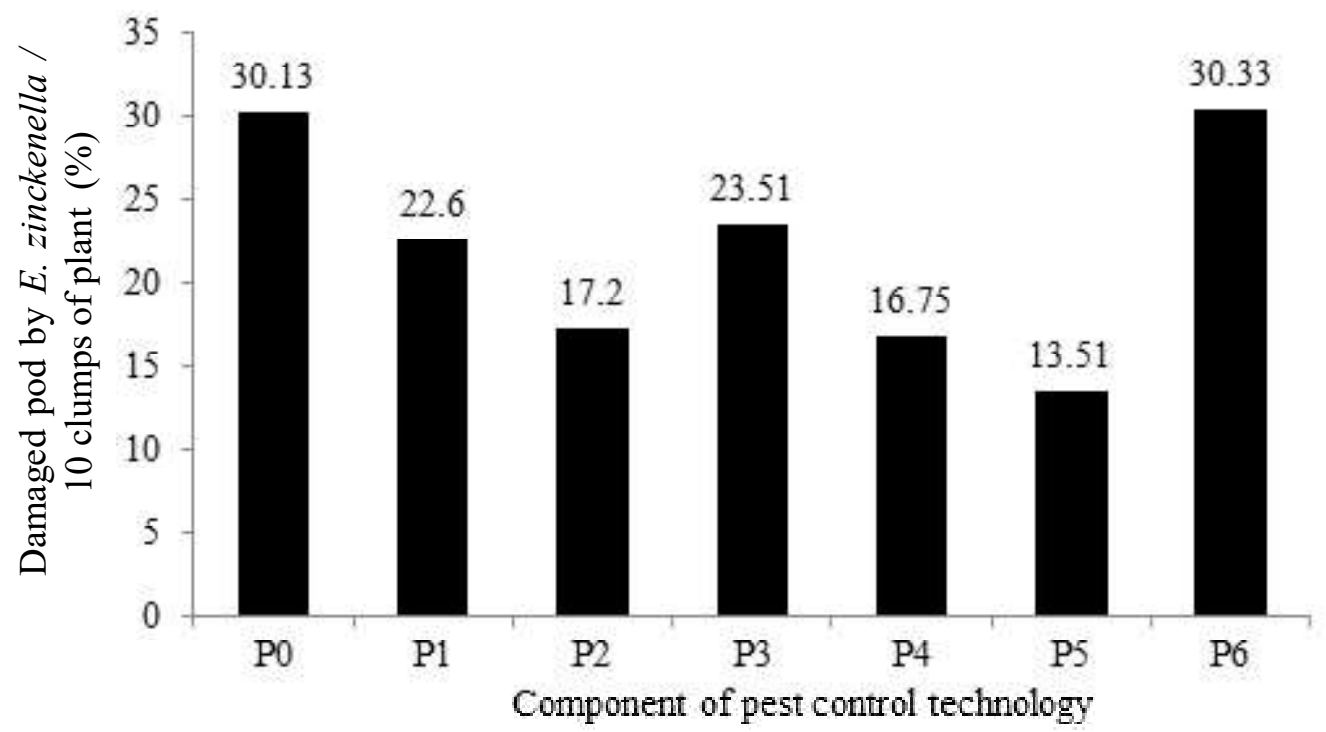

Figure 2. The average number of damaged pod by E. zinckenella/10 clumps of plant. P0 (no pest control); P1 (thiamethoxam + carbofuran + T. bactrae-bactrae + trap crops + lambda-cyhalothrin); P2 (carbofuran + T. bactrae-bactrae + trap crops + lambda-cyhalothrin); P3 (T. bactrae-bactrae + trap crops + lambda-cyhalothrin); P4 (thiamethoxam + carbofuran + L. lecanii); P5 (thiamethoxam + L. lecanii); and P6 (lambda-cyhalothrin). 
insecticides sprayed seven times from the age of 35-70 DAP was not significantly different from control. Control of peanut pod borer pests is more difficult than the control of other pests because larval stages that damage the pod are inside soil. The results of research conducted by Badii et al. (2013) also indicated that the application of lambda-cyhalothrin insecticide for the control of pod borer (Maruca vitrata) attacking pigeon pea was also not significantly different from control treatments resulting in the high number of pod damage.

The pod damage in the $\mathrm{P} 4$ and $\mathrm{P} 2$ treatments was ranged from $16-17 \%$ and not significantly different from the P5 treatment. The efficacy of P4 treatment in suppressing the development of pod borer larvae is thought to be due to the thiamethoxam insecticide compatible with L. lecanii fungi. According to Alizadeh et al. (2007), several types of chemical insecticides, except imidacloprid and amitraz insecticides, are compatible with entomopathogenic $L$. lecanii fungi so that they can increase the efficacy of these biological agents in controlling pests. Meanwhile, destructive observations on $\mathrm{P} 2$ found that E. zinckenella was more interested in laying eggs on soybean plants that were used as trap crops, rather than the peanut plants in treatment plots. With the small number of eggs in peanuts in the plot, the number of larvae formed was also smaller. This condition was observed on the P2 treatment plot which was not significantly different from P5.

P3 treatment showed higher pod damage reaching $23.51 \%$ compared to $\mathrm{P} 2$. This condition was considered to be the role of $T$. bactrae-bactrae was not significant in parasitizing $E$. zinckenella eggs as a result of the application of chemical insecticides. The results of this study were supported by Takada et al. (2001), Mason et al. (2002), Consoli et al. (2009) and Araya et al. (2010), that some types of chemical insecticide active ingredients can negatively affect the longevity and the morphology of parasitoids. Furthermore, Sattar et al. (2011) and Blibech et al. (2015) also explained that chemical insecticide compounds such as deltamethrin, spinosad, indoxacarb, and lufenuron can inhibit the process of oviposition and the emergence of parasitoid T. chilonis. Nevertheless, there are several types of chemical insecticides such as phenvalerate and phenoxycarb that are safe against the development and survival of T. evanescens parasitoid (Carrillo et al., 2009; Abulhay \& Bathi, 2014). According to Hermandez et al. (2011) and Costa et al. (2014), lambda-cyhalothrin and triflumuron insecticides are also safe against the survival of the parasitoid Ganaspidium nigrimanus and T. galloi. Furthermore, emamectin benzoate and clothianidin insecticides were also safe against the behavior and survival of the Cotesia vestalis parasite in citing the caterpillar cabbage Plutella xylostella (Kawazu et al., 2010).

Pod damage in treatments P1, P2 and P3 was still quite high, respectively 22,17 and $23 \%$. This condition was due to the chemical insecticide compound which was applied negatively to the other control components so that the control becomes less optimal. According to Zhao et al. (2012) and Hussain et al. (2012) that the application of chemical insecticide thiamethoxam and carbofuran that is not timely can interfere with the performance of the parasitoid T. chilonis and T. japonicum.

Pod Dry Weight. The yields obtained from each treatment ranged from $4.6-8.2 \mathrm{~kg} /$ plot (Figure 3 ). The lowest yield occurred in the P6 treatment which was only $4.6 \mathrm{~kg} /$ plot. Yields in P6 were not significantly different from $\mathrm{P} 3$ and $\mathrm{P} 0$ treatments with an average dry pod yield was $4.7 \mathrm{~kg} / \mathrm{plot}$. The low yields in the P6 treatment were due to the large number of larvae found inside the pods reaching 20 larvae/ 10 clumps of plants so that pod damage was also quite large. The results of this study indicate that the chemical insecticide from lambda-cyhalothrin which was applied seven times was considered not able to suppress the development of E. zinckenella population because the pod damage was high and not statistically different from the control (P0). This result was in contrast to the research conducted by Gehan \& Abdalla (2006) and Dhaka et al. (2011) which stated that the lambda-cyhalothrin was quite effective for controlling $E$. zinckenella in cowpea. The difference in the efficacy of this study was probably due to the differences in the host plants of E. zinckenella. Peanut pods are in the soil while cowpea pods are on the surface of the soil, thus affecting the bioecology and behavior of the insects. The application of chemical insecticides on plant surfaces will kill the entire structure of pest populations that exist on the plant surface. Conversely, the application of insecticides on plant surfaces is unable or difficult to reach larvae that attack pods under the soil surface.

Dry pod weight in $\mathrm{P} 1$ and $\mathrm{P} 2$ ranges from 7.1 to $7.4 \mathrm{~kg} / \mathrm{plot}$, higher than P3 and P6. The highest dry pod weight observed in the treatments of $\mathrm{P} 4$ and $\mathrm{P} 5$ reaching $8.2 \mathrm{~kg} /$ plot. The high weight of dry pods in both treatments was related to the limited number of damaged pods due to the low number of pod borer larvae populations, especially for P5, which was only 3 larvae, while the number of larvae in P4 was 7/10 clumps of plants. Based on the number of larvae, percentage of damaged pods, and the weight of dried 
pods, we can conclude that L. lecanii technology components combined with thiamethoxam or carbofuran insecticides were effective as control technologies for controlling $E$. zinckenella pod borer.

The effectiveness of $L$. lecanii application caused by the conidia of the entomopathogenic fungus was able to infect variety of insect stages, starting from the egg, larvae and imago (Wang et al., 2007; Shinde et al., 2010; Park \& Kim, 2010). The effication of L. lecanii also due to a wide range of hosts including the order; Homoptera, Hemiptera, Coleoptera, Lepidoptera; Orthoptera, nematodes and plant diseases (Gan et al., 2007; Goettel et al., 2008; Shinya et al., 2008). The advantages of $L$. lecanii was their ability to produce chitinase enzymes with high concentrations, these enzymes function as a degenerator of layers cuticle and toxic in killing host insects (Liu et al., 2003; Lu et al., 2005).

Survival of Natural Enemies. Peanut pod borer control using a combination of various pest control components appears to be safer for the survival of useful insects, especially general predators, Coccinella $\mathrm{sp}$. (Coccinellidae) and Oxyopes sp. (Oxyopidae) and parasitoids order Hymenoptera and Diptera compared to single control component such as application of chemical insecticides only (Figure 4). The highest predator and parasitoids population occurred in treatment $\mathrm{P} 0$, while the lowest population occurred in treatment $\mathrm{P} 3$ and $\mathrm{P} 6$. The high number of predators population, Coccinella sp. and Oxyopes sp. in $\mathrm{P} 0$ was due to the presence of prey populations (B. tabaci and A. glycines) in the crop (Figure 5). Fotukkiaii \& Sahragard (2013) stated that, the population of predators in habitat was determined by the number and types of prey available. Tian et al. (2017) also reported that the abundance of the predator Serangium japonicum (Coleoptera: Coccinellidae) is related to the types of prey populations that exist in the field.

In the P0 treatment, there was a development on the prey population, especially the whiteflies (B. tabaci) and aphid (A. glycines), 216 and 78 each in 10 clumps of plants respectively (Figure 5). The population of both types of prey consists of eggs, nymphs, and imago stages which are a source of food for predators Oxyopes sp. and Coccinella sp. to maintain the survival of both types of predators. Freier et al. (2007) reported that the abundance of predator populations was strongly influenced by the presence of prey populations. The more abundant the prey population in the field, the predator population of the Coccinellidae order were also rapidly increased (Zhao et al., 2013a; Zhao et al., 2013b; Kindlmann et al., 2015).

The lowest number of natural enemy populations was observed at the P6 treatment, especially for the generalist Oxyopes sp., in contrast, the predator population at $\mathrm{P} 1, \mathrm{P} 2, \mathrm{P} 3$, and $\mathrm{P} 4$ was high. Population abundance of Oxyopes sp. at the four treatments was allegedly due to the presence of more prey populations, especially the egg and imago stages of pod borers and other types of pests. This condition was followed the Huseynov's (2006) report that mentioned the

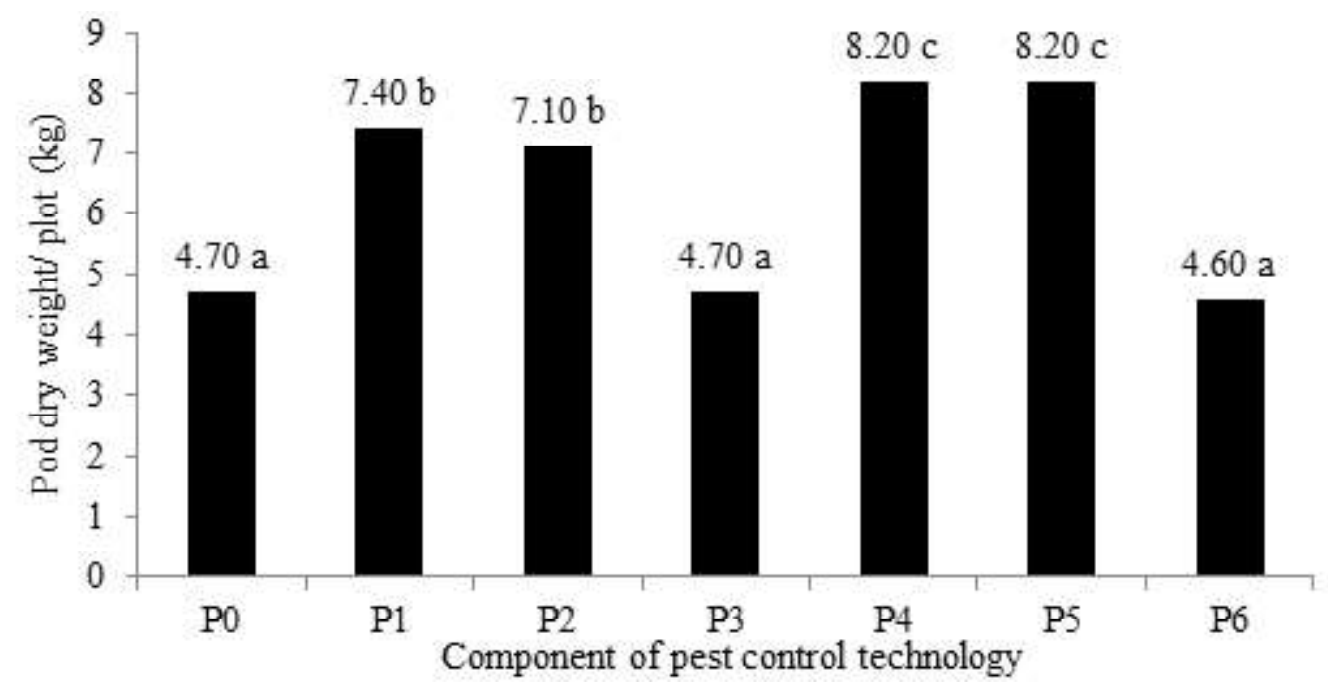

Figure 3. Pod dry weight on each treatment. P0 (no pest control); P1 (thiamethoxam + carbofuran + T. bactraebactrae + trap crops + lambda-cyhalothrin); P2 (carbofuran + T. bactrae-bactrae + trap crops + lambdacyhalothrin); P3 (T. bactrae-bactrae + trap crops + lambda-cyhalothrin); P4 (thiamethoxam + carbofuran + L. lecanii); P5 (thiamethoxam + L. lecanii); and P6 (lambda-cyhalothrin). 
Oxyopes sp. was a generalist predator that can inhabit the soil surface and plant canopy so that it has a fairly high preying ability and a broad range of prey from several types of insects. Generalist predators have a wider chance to survive because they are able to eat various types of prey compared to specialist predators (Huseynov, 2007; Inayat et al., 2011; Rana et al., 2012).
The parasitoid population order Hymenoptera and Diptera at P0 treatment was the highest, while the lowest parasitoid population was observed at P6 treatment (Figure 4). The parasitoid population in P1, P2 and P3 were relatively high although not as abundant as in the P0 treatment, this condition was due to the application of chemical insecticide on the three treatments in the seed and planting time (P1), and scheduled applications

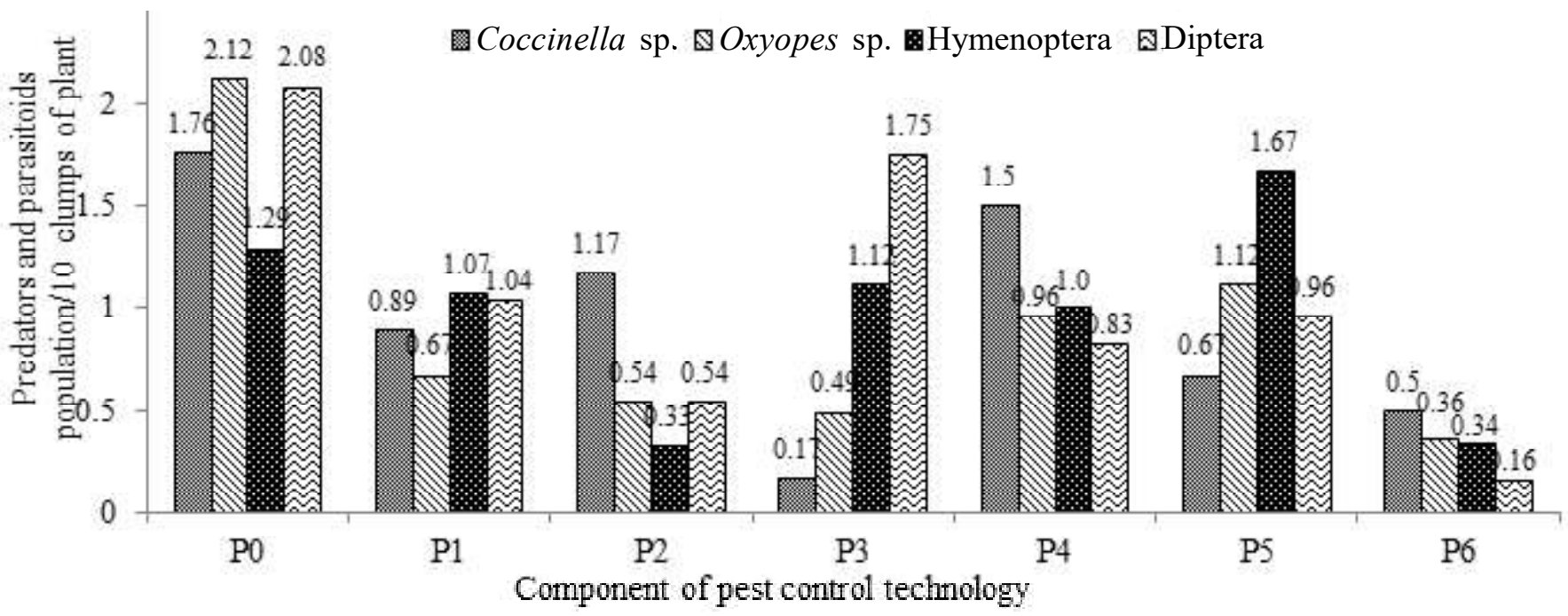

Figure 4. Predators and parasitoids population at each treatment plot. P0 (no pest control); P1 (thiamethoxam + carbofuran $+T$. bactrae-bactrae + trap crops + lambda-cyhalothrin); $\mathrm{P} 2$ (carbofuran $+T$. bactraebactrae + trap crops + lambda-cyhalothrin); P3 (T. bactrae-bactrae + trap crops + lambda-cyhalothrin); P4 (thiamethoxam + carbofuran + L. lecanii); P5 (thiamethoxam + L. lecanii); and P6 (lambdacyhalothrin).

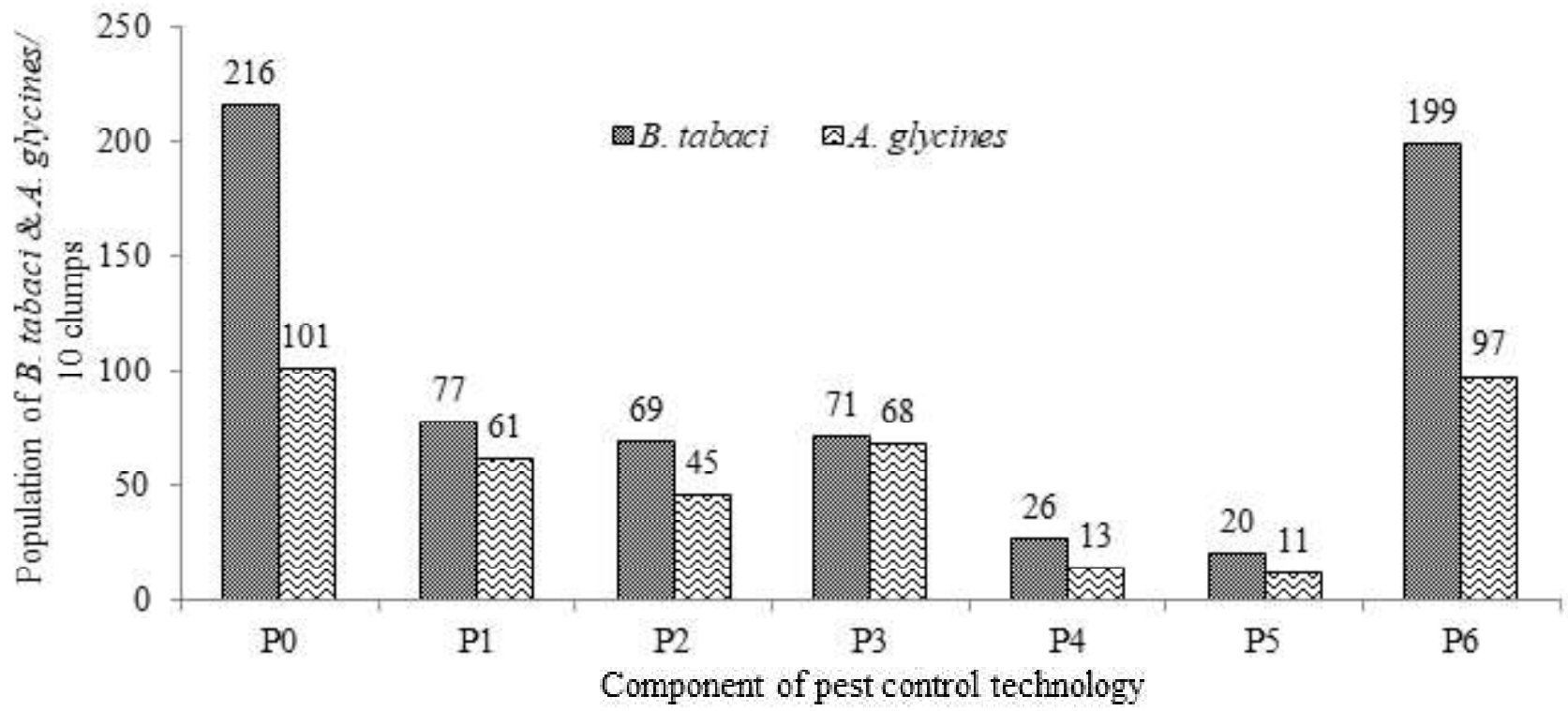

Figure 5. Population of B. tabaci and A. glycines/10 clumps of plant at each treatment plot. P0 (no pest control); $\mathrm{P} 1$ (thiamethoxam + carbofuran + T. bactrae-bactrae + trap crops + lambda-cyhalothrin); P2 (carbofuran + T. bactrae-bactrae + trap crops + lambda-cyhalotrin); P3 (T. bactrae-bactrae + trap crops + lambdacyhalothrin); P4 (thiamethoxam + carbofuran + L. lecanii); P5 (thiamethoxam + L. lecanii); and P6 (lambda-cyhalothrin). 
every week starting from 35-70 DAP (P2 and P3). According to Sugiyama et al. (2011) and Shimoda et al. (2011), parasitoid groups are more susceptible to chemical insecticide applications than pest insects. Meanwhile, the high parasitoid population in P1, P2, and P3 was probably due to the presence of soybean trap crops around the plot so that the crops can function as a shelter (reservoir) for parasitoids. According to Noma et al. (2010) that the abundance of parasitoid populations was related to the presence of hosts and crops as a shelter or to maintain their survival.

The observed parasitoids were identified as a member of Hymenoptera, meanwhile, parasitoids from the Hymenoptera had the ability to parasitize several types of hosts, thus the high diversity of the host population would directly influence the number of the observed parasitoid population. Some of the results from previous studies also shown that parasitoids from the order Hymenoptera have the ability to parasitize the broad range of hosts, on various types and stages of pests (Herz \& Hassan, 2006; Kalyebi et al., 2014).

In P4 and P5 treatments the parasitoid Hymenoptera and Diptera populations were higher than P1, P2, P3 and P0 although both treatments also used chemical insecticide and $L$. lecanii biopesticides. This condition was caused by the application of chemical insecticides only for seed treatment and planting so it was suspected that exposure to chemical insecticide residues in the fields was low and has little impact on the parasitoid abundance. Besides, the parasitoids are highly mobile so that the L. lecanii conidia that applied did not inoculate the two types of parasitoids. According to Al-Deghairi (2009) the application of entomopathogenic fungus Beauveria bassiana for the control of whitefly (B. tabaci) appears to be more compatible with natural enemies such as parasitoids from the order Hymenoptera. Furthermore, Velez (2008) reports that entomopathogenic fungus $L$. longisporum can be combined with predators of the order Diptera. Ren et al. (2010) and Cuthbertson et al. (2010) explained that the application of L. muscarium entomopathogenic fungus were safe for the survival of parasitoids and predators, especially in adult stages.

\section{CONCLUSION}

The application of biopesticides containing conidia of L. lecanii fungus combined with carbofuran or thiamethoxam insecticides was effective in controlling pod borer (E. zinckenella) and maintain the survival of natural enemies (predators and parasitoids). The thiamethoxam, carbofuran, lambda-cyhalothrin, parasitoid T. bactrae-bactrae, and trap crops could be applied in an integrated way to control E. zinckenella. The application of lambda-cyhalothrin insecticide has not been able to suppress the development of population E. zinckenella and kill the presence of natural enemies. L. lecanii biopesticides combined with thiamethoxam or carbofuran insecticides was recommended as a technology for controlling peanut pod borer.

\section{ACKNOWLEDGMENTS}

The author would like to acknowledge the Indonesian Agency for Agricultural Research and Development (IAARD) as funding of this research, the Indonesian Center for Food Crops Research and Development (ICFORD), as well as the Indonesian Legumes and Tuber Crops Research Institute (ILETRI) for trusting the authors to carried out this research. Acknowledgments were also conveyed to the Lampung Assessment Institute for Agricultural Technology (Lampung AIAT) for granting land use permits of pod borer endemic area in Natar Experimental Fields so that they were very representative in accordance with the aims and objectives of the study.

\section{REFERENCES}

Abdou GY \& Abdalla EF. 2006. Evaluation of some selected pesticides against the two pod borers Helicoverpa armigera and Etiella zinckenella population infesting cowpea in the newly reclaimed regions. Res. Agric. Biol. Sci. 2(6): 578-583.

Abulhay HS \& Bathi MH. 2014. Effect of some insecticides on the egg parasitoid, Trichogramma evanescens Westword (Hymenoptera: Trichogrammatidae). J. Al-Nahrain Univ. 17(3): 116-123.

Al-Deghairi MA. 2009. Combining effect of Beauveria bassiana (Bals.) and Eretmocerus mundus Mercet (Hymenoptera: Aphelinidae) on sweetpotato whitefly Bemisia tabaci Gennadius (Aleyrodidae; Hemiptera). J. Entomol. 6(2): 7281.

Alizadeh A, Samih MA, \& Izadi H. 2007. Compatibility of Verticillium lecanii (Zimm.) with several pesticides. Commun. Agric. Appl. Biol. Sci. 72(4): 1011-1015. 
Apriyanto D, Sriwidodo, \& Priyatiningsih. 2008. Incidence of soybean pod borer on groundnut (Arachis hypogaea L.) in Bengkulu. J. Akta Agrosia. 11(1): 41-46.

Apriyanto D, Yoga DH, \& Mulyadi. 2009. Penampilan penggerek polong kedelai, Etiella zinckenella Treitschke (Lepidoptera: Pyralidae), dan pemilihan inang pada kedelai dan kacang tanah. J. Akta Agrosia. 12(1): 62-67.

Apriyanto D, Toha B, Priyatiningsih, \& Suryati D. 2010. Penampilan ketahanan enam varietas kacang tanah terhadap penggerek polong (Etiella zinckenella Trietschke) di dataran tinggi dan dataran rendah Bengkulu. J. HPT Tropika. 10(1): $13-19$.

Araya JE, Araya M, \& Guerrero MA. 2010. Effects of some insecticides applied in sublethal concentrations on the survival and longevity of Aphidius ervi (Haliday) (Hymenoptera: Aphidiidae) adults. Chil. J. Agric. Res. 70(2): 221-227.

Badii KB, Bae A, \& Sowley ENK. 2013. Efficacy of some lambda-cyhalothrin-based insecticides in control of major field pests of cowpea (Vigna unguiculata L.). IJSTR. 2(4): 76-81.

Baliadi Y. 2006. Dominansi dan keragaman penyakit utama kedelai, kacang tanah, dan kacang hijau di Jawa Timur dan Nusa Tenggara Barat. Laporan Survei Lapang Evaluasi Status OPT KacangKacangan dan Musuh Alaminya. Balai Penelitian Tanaman Aneka Kacang dan Umbi. Malang.

Baliadi Y \& Rahmiana AA. 2010. Bioekologi dan pengendalian penggerek polong, Etiella zinckenella Tr. pada kacang tanah. Laporan Tengah Tahun 2010. Balai Penelitian Tanaman Aneka Kacang dan Umbi. Malang.

Blibech I, Ksantini M, Jardak T, \& Bouaziz M. 2015. Effect of insecticides on Trichogramma parasitoids used in biological control against Prays oleae insect pest. Adv. Chem. Engineer. Sci. 5: 362-372.

Carrillo D, Peña JE, \& Rogers ME. 2009. Relative susceptibility of Haeckeliania sperata (Hymenoptera: Trichogrammatidae) to pesticides used in citrus and ornamental systems in Florida. J. Econ. Entomol. 102(3): 905-912.
Cônsoli FL, Parra JRP, \& Hassan SA. 1998. Sideeffects of insecticides used in tomato fields on the egg parasitoid Trichogramma pretiosum Riley (Hym., Trichogrammatidae), a natural enemy of Tuta absoluta (Meyrick) (Lep., Gelechiidae). J. Appl. Entomol. 122(1-5): 4347.

Costa MA, Moscardini VF, Gontijo PdaC, Carvalho GA, de Oliveira RL, \& de Oliveira HN. 2014. Sublethal and transgenerational effects of insecticides in developing Trichogramma galloi (Hymenoptera: Trichogrammatidae). Ecotoxicology. 23(8): 1399-1408.

Cuthbertson AGS, Blackburn LF, Northing P, Luo W, Cannon RJC, \& Walters KFA. 2010. Chemical compatibility testing of the entomopathogenic fungus Lecanicillium muscarium to control Bemisia tabaci in glasshouse environment. Int. J. Environ. Sci. Technol. 7(2): 405-409.

Damayanti D, Sutrisno, Pardal SJ, Herman M, Ekramli, Sundari R, \& Ibrahim E. 2001. Bioasai tanaman kedelai transgenik R2 terhadap Etiella zinckenella Tr. Prosiding Seminar Hasil Penelitian Rintisan dan Bioteknologi Tanaman. pp. 118-124. Balai Penelitian Bioteknologi dan Sumberdaya Genetik Pertanian, Bogor.

Dhaka SS, Singh G, Ali N, Mittal V, \& Singh DV. 2011. Efficacy of novel insecticides against pod borer, Etiella zinckenella (Treitschke) in vegetable pea. Crop Res. 42: 331-335.

Fotukkiaii SM \& SahragardA. 2013. Functional response of Serangium montazerii (Col.: Coccinellidae) to different densities of Dialeurodes citri (Hem.: Aleyrodidae) an open-pacth approach. $J$. Entomol. Soc. Iran. 33(2): 1-7.

Freier B, Triltsch H, Möwes M, \& Moll E. 2007. The potential of predators in natural control of aphids in wheat: results of a ten-year field study in two German landscapes. BioControl. 52: 775-788.

Gan Z, Yang J, Tao N, Liang L, Mi G, Li J, \& Zhang KQ. 2007. Cloning of the gene Lecanicillium psalliotae chitinase Lpchit1 and identification of its potential role in the biocontrol of root-knot nematode Meloidogyne incognita. Appl. Microbiol. biotechnol. 76(6): 1309-1317. 
Ganeshi J. 2013. Tingkat serangan hama penggerek polong Etiella zinckenella Treit (Lepidoptera: Pyralidae) pada pertanaman kacang tanah (Arachis hypogaea L.) di Kabupaten Pasaman Bara. Skripsi. Universitas Andalas, Padang.

Gehan YA \& Abdalla EF. 2006. Evaluation of some selected pesticides against the two pod borers, Helicoverpa armigera and Etiella zinckenella population infesting cowpea in the newly reclaimed regions. J. Agric. Biol. Sci. 2(6): 578583.

Goettel MS, Koike M, Kim JJ, Aiuchi D, Shinya R, \& Brodeur J. 2008. Potential of Lecanicillium spp. for management of insects, nematodes and plant diseases. J. Invertebr. Pathol. 98(3): 256-261.

Hedayati MT, Pasqualotto AC, Warn PA, Bowyer P, \& Denning DW. 2007. Aspergillus flavus: human pathogen, allergen and micotoxin producer. Microbiology. 153(6): 1677-1692.

Hernández R, Harris M, \& Liu TX. 2011. Impact of insecticides on parasitoids of the leafminer, Liriomyza trifolii, in pepper in south Texas. $J$. Insect Sci. 11(1): 1-4.

Herz A \& Hassan SA. 2006. Are indigenous strains of Trichogramma sp. (Hym., Trichogrammatidae) better candidates for biological control of lepidopterous pests of the olive tree? Biocontrol Sci. Technol. 16(8): 841-857.

Huseynov EF. 2006. The prey of the lynx spider Oxyopes globifer (Araneae: Oxyopidae) associated with a semidesert dwarf shrub in Azerbaijan. J. Arachnol. 34(2): 422-426.

Huseynov EF. 2007. Natural prey of the lynx spider Oxyopes lineatus (Araneae: Oxyopidae). Entomol. Fennica 18: 144-148.

Hussain D, Ali S, Mushfaq-ul-Hassan M, Ali S, Saleem M, \& Nadeem S. 2012. Evaluation of toxicity of some new insecticides against egg parasitoid Trichogramma chilonis (Ishii) (Hymenoptera: Trichogrammitidae). Pak. J. Zool. 44(4): 11231127.

Inayat TP, Rana SA, Rana N, Ruby T, Siddiqui MJI, \& Abbas MN. 2011. Predator-prey relationship among selected species in the croplands of central Punjab Pakistan. Pak. J. Agric. Sci. 48(2): 153157.
Isaka M, Kittakoop P, Kirtikara K, Hywel-Jones N, \& Thebtaranonth Y. 2005. Bioactive substances from insect pathogenic fungi. Acc. Chem. Res. 38(10): 813-823.

Kalyebi A, Hassan S, Sithananthan S, \& Mueke JM. 2014. Parasitization of Helicoverpa armigera (Lepidoptera: Noctuidae) by four indigenous trichogramatid species/strains in a mixed croping system of tomato and okra. Adv. Res. 2(4): 188194.

Kawazu K, Shimoda T, \& Suzuki Y. 2010. Effect of insecticides on the foraging behaviour and survival of Cotesia vestalis, a larval parasitoid of the diamondback moth, Plutella xylostella. J. Appl. Entomol. 135(9): 647-657.

Kindlmann P, Yasuda H, Kajita Y, Sato S, \& Dixon AFG. 2015. Predator efficiency reconsidered for ladybird-aphid system. Front. Ecol. Evol. 3(27): $1-5$.

Liu BL, Kao PM, Tzeng YM, \& Feng KC. 2003. Production of chitinase from Verticillium lecanii F091 using submerged fermentation. Enzyme Microb. Technol. 33(4): 410-415.

Lu ZX, Laroche A, \& Huang HC. 2005. Isolation and characterization of chitinases from Verticillium lecanii. Can. J. Microbiol. 51(12): 1045-1055.

Mason PB, Erlandson MA, Elliott RH, \& Harris BJ. 2002. Potential impact of spinosad on parasitoids of Mamestra configurata (Lepidoptera: Noctuidae). Can. Entomol. 134(1): 59-68.

Murakoshi S, Ichinoe M, Suzuki A, Kanaoka M, Isogai A, \& Tamura S. 1978. Presence of toxic substance in fungus bodies of the entomopathogenic fungi Beauveria bassiana and Verticillium lecanii. Appl. Entomol. Zool. 13(2): 97-102.

Noma T, Gratton C, Colunga-Garcia M, Brewer MJ, Mueller EE, Wyckhuys KA, Heimpel GE, \& O'Neal ME. 2010. Relationship of soybean aphid (Hemiptera: Aphididae) to soybean plant nutrients, landscape structure, and natural enemies. Environ. Entomol. 39(1): 31-41.

Norton G, Taylor M, Thiele K, \& Pickering J. 2000. Identification Guide to Insect Orders. Lucid Professional Demonstration Key (CD based). The University of Queensland. Queensland. 
Park H \& Kim K. 2010. Selection of Lecanicillium strain with high virulence against developmental stages of Bemisia tabaci. Mycobiology. 38(3): 210-214.

Permana AD, Johari A, Putra RE, Sastrodihardjo S, \& Ahmad I. 2012. The influence of trichome characters of soybean (Glycine max Merrill) on oviposition preference of soybean pod borer Etiella zinckenella Treitschke (Lepidoptera: Pyralidae) in Indonesia. J. Entomol. Nematol. 4(3): 15-21.

Prayogo Y. 2009. Kajian Cendawan Entomopatogen Lecanicillium lecanii (Zimm.) (Viegas) Zare \& Gams) untuk Menekan Perkembangan Telur Hama Pengisap Polong Kedelai Riptortus linearis (F.) (Hemiptera: Alydidae). Dissertation. Institut Pertanian Bogor, Bogor.

Prayogo Y, Bayu MSI, \& Rahmiana AA. 2012. Teknologi pengendalian hama penggerek polong kacang tanah Etiella zinckenella di lahan kering masam. Laporan Hasil Penelitian Tahun 2012. Balai Penelitian Tanaman Aneka Kacang dan Umbi, Malang.

Rana SA, Ruby T, Rana N, Afzal M, Mahmood-ulHassan, \& Siddiqui MJI. 2012. Predator-prey association among selected arthropod species in the cropland of mixed crop zone (MCZ) and cotton-wheat zone (CWZ). J. Anim. Plant Sci. 22(4): 1019-1023.

Reddy KRN, Salleh B, Saad B, Abbas HK, Abel CA, \& Shier WT. 2010. An overview of mycotoxin contamination in foods and its implications for human health. Toxin Rev. 29(1): 3-26.

Ren SX, Ali S, Huang Z, \& Wu JH. 2010. Lecanicillium muscarium as microbial insecticide against whitefly and its interaction with other natural enemies. In: Mendez-Vilas A (Ed.). Current Research, Technology and Education Topics in Applied Microbiology and Microbial Biotechnology. pp. 339-349. Formatex Research Center.

Rodrigues ENL, Mendonça JrMdeS, Fritz LL, Heinrichs EA, \& Fiuza L. 2013. Effect of the insecticide lambda cyhalothrin on rice spider populations in southern Brazil. Zoologia. 30(6): 615-622.

Sattar S, Farmanullah, Saljoqi AR, Arif M, Sattar H, \& Qazi JI. 2011. Toxicity of some new insecticides against Trichogramma chilonis (Hymenoptera:
Trichogrammatidae) under laboratory and extended laboratory conditions. Pak. J. Zool. 43(6): 1117-1125.

Schell S \& Latchininsky A. 2007. Insect Identification. Renewable Resources. University of Wyoming. Laramie.

Shimoda T, Yara K, \& Kawazu K. 2011. The effects of eight insecticides on the foraging behavior of the parasitoid wasp Cotesia vestalis. J. Plant Interac. 6(2-3): 189-190.

Shinde SV, Patel KG, Purohit MS, Pandya JR, \& Sabalpara AN. 2010. "Lecanicillium lecanii (Zimm.) Zare and Gams" an important biocontrol agent for the management of insect pests. Agric. Res. 31(4): 235-252.

Shinya R, Aiuchi D, Kushida A, Tani M, Kuramochi K, \& Koike M. 2008. Pathogenicity and its mode of action different sedentary stages of Heterodera glycines (Tylenchida: Heteroderidae) by Verticillium lecanii hybrid strains. Appl. Entomol. Zool. 43(2): 227-213.

Sugiyama K, Katayama H, \& Saito T. 2011. Effect of insecticides on the mortalities of three whitefly parasitoid species, Eretmocerus mundus, Eretmocerus eremicus and Encarsia formosa (Hymenoptera: Aphelinidae). Appl. Entomol. Zool. 46(3): 311-317.

Sutrisno, Pardal SJ, Damayanti D, Herman M, Sundari R, \& Ibrahim E. 2002. Bioasai tanaman kedelai transgenik pin Il terhadap hama penggerek polong (Etiella zinckenella, Treitschke). Prosiding Seminar Hasil Penelitian Rintisan dan Bioteknologi Tanaman. pp. 167-172. Balai Penelitian Bioteknologi dan Sumberdaya Genetik Pertanian, Bogor.

Takada Y, Kawamura S, \& Tanaka T. 2001. Effects of various insecticides on the development of the egg parasitoid Trichogramma dandrolini (Hymenoptera: Trichogrammatidae). J. Econ. Entomol. 94(6): 1340-1343.

Tengkano W, Supriyatin, Suharsono, Bedjo, Prayogo Y, \& Purwantoro. 2007. Status hama kedelai dan musuh alami di lahan kering masam Lampung. Iptek Tanaman Pangan. 2(1): 93-109.

Tengkano W. 2007. Daerah penyebaran hama kedelai dan musuh alaminya di lahan kering masam Sumatera Selatan. In: Harnowo D, Rahmiana AA, Suharsono, Adie MM, Rozi F, Subandi, Makarim 
AK (eds.). Peningkatan Produksi Kacangkacangan dan Umbi-umbian Mendukung Kemandirian Pangan. pp. 369-383. Pusat Penelitian dan Pengembangan Tanaman Pangan, Bogor.

Thangavel B, Palaniappan K, Pillai KM, Subbarayalu M, \& Madhaiyan R. 2013. Pathogenicity, ovicidal action, and median lethal concentrations $\left(\mathrm{LD}_{50}\right)$ of entomopathogenic fungi against exotic spiralling whitefly, Aleurodicus dispersus Russell. J. Pathog. 2013: 393787.

Tian M, Wei Y, Zhang S, \& Liu T. 2017. Suitability of Bemisia tabaci (Hemiptera: Aleyrodidae) biotype-B and Myzus persicae (Hemiptera: Aphididae) as prey for the ladybird beetle Serangium japonicum (Coleoptera: Coccinellidae). Eur. J. Entomol. 114: 603-608.

Van den Berg H, Shepard BM, \& Nasikin. 1998. Damage incidence by Etiella zinckenella in soybean in East Java, Indonesia. Int. J. Pest Manage. 44(3): 153-159.

Van den Berg H, Aziz A, \& Machrus M. 2000. Onfarm evaluation of measures to monitor and control soybean pod-borer Etiella zinckenella in East Java, Indonesia. Int. J. Pest Manage. 46(3): 219-224.
Velez J. 2008. Compatibility of the entomopathogenic fungus Lecanicillium longisporum (Petch) Zare \& Gams with the predatory midge Aphidoletes aphidimyza Rondani (Diptera: Cecidomyiidae). Thesis. Simon Fraser University, Canada.

Wang L, Huang J, You M, Guan X, \& Liu B. 2007. Toxicity and feeding deterrence of crude toxin extracts of Lecanicillium (Verticillium) lecanii (Hyphomycetes) against sweet potato whitefly, Bemisia tabaci (Homoptera: Aleyrodidae). Pest Manag. Sci. 63(4): 381-387.

Zhao X, Wu C, Wang Y, Cang T, Chen L, Yu R, \& Wang Q. 2012. Assessment of toxicity risk of insecticides used in rice ecosystem on Trichogramma japonicum, an egg parasitoid of rice lepidopterans. J. Econ. Entomol. 105(1): 92101.

Zhao ZH, Hui C, He DH, \& Ge F. 2013a. Effects of position within wheat field and adjacent habitats on the density and diversity of cereal aphids and their natural enemies. BioControl. 58(6): 765776.

Zhao ZH, Hui C, Ouyang F, Liu JH, Guan XQ, He DH, \& Ge F. 2013b. Effects of inter-annual landscape change on interactions between cereal aphids and their natural enemies. Basic Appl. Ecol. 14(6): 472-479. 